\title{
Quality improvement of gear wheels obtained from polymer materials by shaving process (Rapid communication)
}

\author{
Olimpia Markowska ${ }^{1)}$ (ORCID ID: 0000-0001-6396-9044), Katarzyna Bulanda ${ }^{2), *)}{ }_{(0000-0002-5330-5719),}$ \\ Magdalena Zajdel ${ }^{3)}(0000-0003-3053-5017)$
}

DOI: dx.doi.org/10.14314/polimery.2021.5.4

\begin{abstract}
The geometric accuracy of gears obtained by injection molding before and after finishing by shaving process has been compared. Significant assumptions in the application of this method to the finishing of polymer gears are presented. There is a clear influence of the applied technology on the dimensional stability improvement of the tested gears rim made of composite PA66 matrix containing $35 \mathrm{wt} \%$ glass fibers. The tested gears made of the composite materials used in some drive systems can successfully replace this type of machine elements made of metals.
\end{abstract}

Keywords: gears, shaving, polymer materials, PA66, fiberglass.

\section{Poprawa jakości kół zębatych otrzymanych z materiałów polimerowych metodą wiórkowania}

Streszczenie: $W$ pracy porównano dokładność geometryczną kół zębatych otrzymanych metodą wtryskiwania przed i po obróbce wykańczającej metodą wiórkowania. Przedstawiono istotne założenia dotyczące zastosowania tej metody do obróbki wykańczającej polimerowych kół zębatych. Zaobserwowano wyraźny wpływ zastosowanej obróbki na poprawę stabilności wymiarowej wieńca badanych kół zębatych z kompozytu na osnowie PA66 zawierającego 35\% mas. włókna szklanego. Koła zębate $\mathrm{z}$ badanych materiałów kompozytowych mogą z powodzeniem być zamiennikami tego typu elementów wykonanych z metali.

Słowa kluczowe: koła zębate, wiórkowanie, materiały polimerowe, PA66, włókno szklane.

The development of modern polymer materials has contributed to the more and more common use of polymer gears, which due to its properties, often successfully replace steel gears. Polymer gears can be manufactured by milling, chiselling and broaching, or for high volume series by injection molding.

The basic requirements for toothed gears are: high reliability, low weight in relation to the transmitted power, low production and operating costs. Therefore, it is difficult to underestimate the advantages of polymer gear wheels: reduced weight and lower inertia due to the lower material density, ability to absorb shocks and vibrations due to the flexibility of the material, significantly reduced noise, and low friction coefficient. In

\footnotetext{
1) Rzeszow University of Technology, Department of Mechanical Engineering, al. Powstańców Warszawy 8, 35-959 Rzeszów, Poland

2) Rzeszow University of Technology, Department of Polymer Composites, al. Powstańców Warszawy 6, 35-959 Rzeszów, Poland

3) SPLAST Sp. z o.o., Lotników 13, 38-400 Krosno, Poland

*) Author for correspondence: k.bulanda@prz.edu.pl
}

most of the cases they do not require lubrication, and can be used in humid environments and food preparation areas. Of course, despite many advantages, polymer gears have also disadvantages, such as lower load capacity compared to steel gears of similar sizes. Polymer gears cannot have the same high tolerances as metal gears can have. Polymeric materials are less dimensionally stable compared to steel, which causes dimensional changes due to the temperature and humidity conditions [1, 2].

The aim of the works described in the article is to improve the accuracy of the dimensions of gears by applying finishing machining with the use of shaving [3].

\section{EXPERIMENTAL PART}

\section{Materials}

Test fittings were made of the following materials:

- PA66 + 35 wt \% glass fiber (GF), a DuPont product (USA), marked as PA35GF, 
T a b l e 1. Parameters of the drying and injection molding process

\begin{tabular}{l|c|c|c}
\hline \multicolumn{1}{c|}{ Parameter } & \multicolumn{2}{c}{ Composite } \\
\cline { 2 - 4 } & PA35GF & PA50GF & PPA35GF \\
\hline Drying time, $\mathrm{h}$ & $2-4$ & $2-4$ & $6-8$ \\
Drying temperature, ${ }^{\circ} \mathrm{C}$ & 80 & 80 & 100 \\
Acceptable moisture level, \% & 0.2 & 0.2 & 0.1 \\
Injection temperature $\min -\max ,{ }^{\circ} \mathrm{C}$ & $280-290$ & $285-305$ & $320-330$ \\
Mold temperature $\min -\max ,{ }^{\circ} \mathrm{C}$ & $70-120$ & $70-120$ & $140-180$ \\
\hline
\end{tabular}

- PA66 + 50 wt \% GF, a DuPont product (USA), marked as PA50GF,

- PPA + 35 wt \% GF, a DuPont product (USA), marked as PPA35GF.

\section{Obtaining test fittings}

The test fittings were obtained with the injection technique using an ENGEL injection molding machine. Prior to injection, the polymers were dried to eliminate any moisture that could cause molded parts to fail during the process and cause faulty test results. Table 1 presents the parameters of the drying and the injection molding process.

\section{Coordinate measurements of the tested gears}

The analysis of the geometric shape mapping accuracy of the tested gears was performed with the use of a noncontact optical system based on the ATOS Triple Scan II Blue Light optical coordinate scanner by GOM at the
Department of Mechanical Engineering at the Rzeszow University of Technology and the research methodology described earlier $[4,5]$. The gears were tested consecutively after four shaving processes.

\section{Shaving of polymer gears}

The method developed and described in this publication allows to increase the efficiency of the gear machining process, which consists in the cooperation of the machined gear with the gear being a tool (Fig. 1).

For the shaving of the tested gears, a CCMetal milling machine was used, equipped with a designed shaving cutter (Fig. 2) and a computer controlling the process.

EUROFLUID coolant - Berucut RMO TC 18 Package, sprayed in place of processing, was used to ensure the appropriate shaving temperature. Shaving was carried out in four stages, removing the excess material so as to obtain the best dimensional tolerances. Dimensional accuracy tests with an optical scanner were performed after each shaving step.

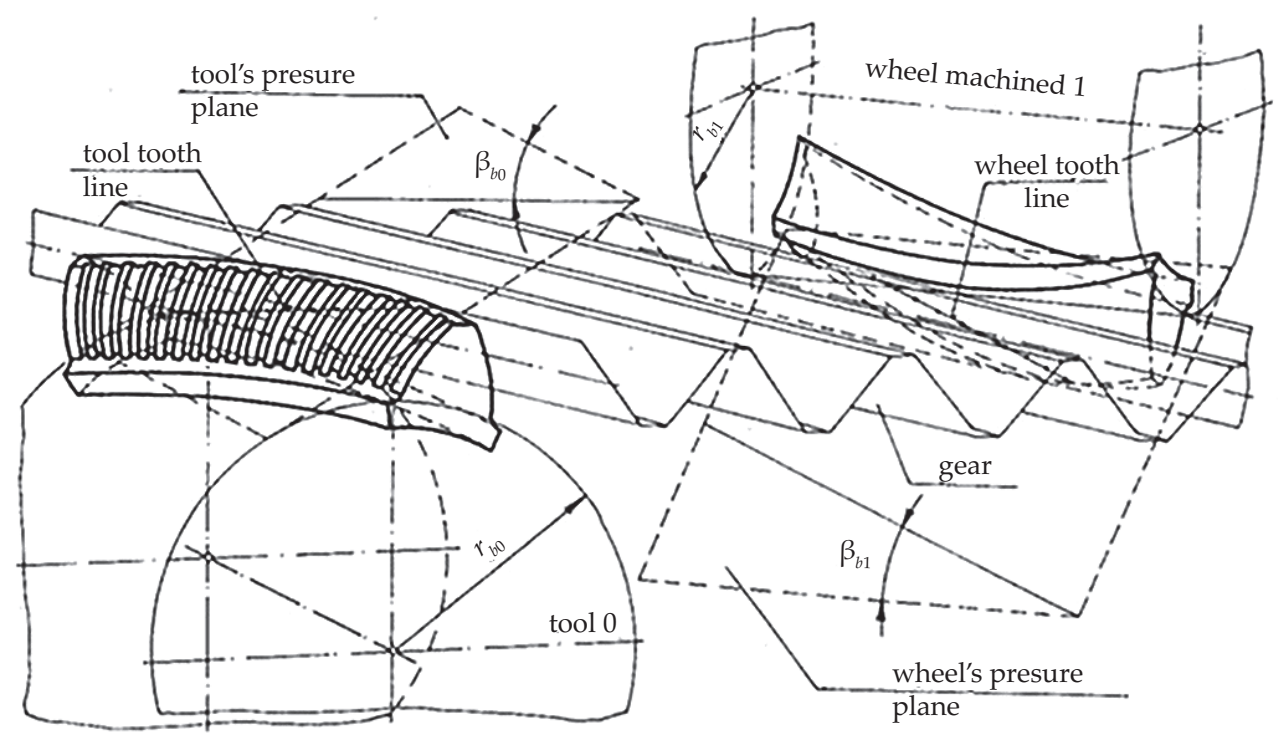

Fig. 1. The meshing geometry of the shaving cutter with the machined wheel in the developed view: $r_{b}-$ radius of the main wheel, $\beta_{b}$-tooth line inclination angle on the main wheel [3] 


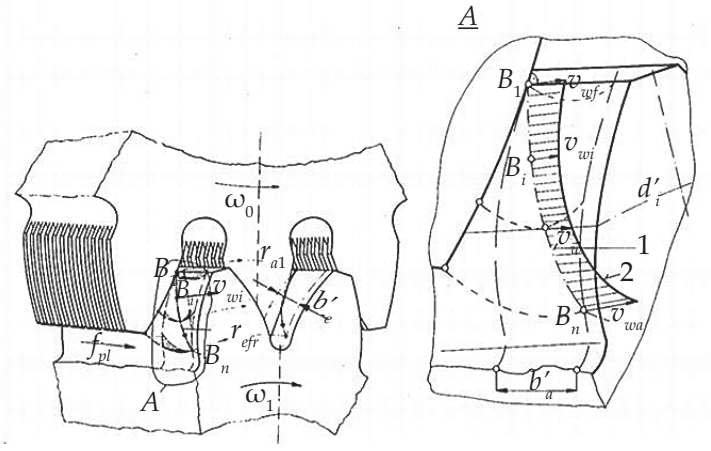

Fig. 2. Image of one cutting edge cooperation of the shaving cutter on the active side of the meshing, where: $r_{a}$ - radius of the tip, $r_{c f}$-radius of the active contour at the base, $\omega$ - angular velocity, $f_{p l}$ - longitudinal feed, $B_{l} B_{n}$ - trajectory of the $B_{i}$ point contact at the level of the contour, $v_{w i}$ - resultant of the cutting speed at $B_{i}$ point, $b_{c}$ - width of the machining zone [3]

\section{RESULTS AND DISCUSSION}

The gears were tested after shaving treatment. Table 2 and selected measurement protocols (Fig. 3) show the geometric accuracy of the test model (gear), made of PA35GF, PA50GF and PPA35GF composites by injection molding, after its shaving treatment. The purpose of the shaving process is to improve the quality of the treated surface by removing inaccuracies resulting from warping of the composite material after the injection process. The applied method of processing allows to remedy these shortcomings very quickly, however, the conditions of this process should be optimized. As it is known, polymer materials are very sensitive to overheating, therefore machining is often carried out with the use of various types of coolants, which must be chemically inert to the polymer material used.

The analysis of the accuracy of gear manufacturing was presented in the GOM Inspect V7.5 program in the form of detailed dimensional deviations determined at selected points of the wheel surface (Table 2 and Fig. 3). On the basis of the gear deviation report obtained from PA35GF by injection method with the 3D-CAD nominal model, clear discrepancies in dimensions on the wheel rim can be noticed (Fig. 3a), which are in the range of +0.371 to $+0.017 \mathrm{~mm}$. The occurrence of such discrepancies in the dimensions of the nominal model and the tested gears may result, inter alia, from warping and shrinkage of the polymer material or possibly not optimized conditions of the injection process.

Then, measurements of the wheel dimensional accuracy were carried out after subsequent shaving stages. The measurement results are presented in Table 2 and Figs. 3b-e. On the basis of the obtained test results, it can be concluded that the shaving process significantly improved the geometric accuracy of the gears obtained from the PA6635GF composite, as evidenced by small size discrepancies (Fig. 3e), ranging from +0.034 to $-0.008 \mathrm{~mm}$.

On the basis of the obtained test results presented in Table 2, it can be concluded that the best test results were obtained for gears made of PA50GF (PA66 matrix com-

$\mathrm{T}$ a b 1 e 2. The results of the dimensional accuracy measurements on the rim of the gear treated with the use of the designed shaving cutter (Fig. 2).

\begin{tabular}{|c|c|}
\hline $\begin{array}{c}\text { PA35GF } \\
\text { Polymer gear made of composite PA66 }+35 \mathrm{wt} \% \text { GF (glass fiber) }\end{array}$ & $\begin{array}{l}\text { The range of dimensional and shape accuracy on the rim } \\
\text { of a polymer gear wheel, } \mathrm{mm}\end{array}$ \\
\hline before the shaving process & from +0.371 to +0.017 \\
\hline after a single pass of shaving cutter & from +0.287 to +0.011 \\
\hline after a two passes of shaving cutter & from +0.167 to +0.009 \\
\hline after a three passes of shaving cutter & from +0.096 to -0.004 \\
\hline after a four passes of shaving cutter & from +0.034 to -0.008 \\
\hline $\begin{array}{c}\text { PA50GF } \\
\text { Polymer gear made of composite PA66 }+50 \mathrm{wt} \% \text { GF (glass fiber) }\end{array}$ & $\begin{array}{l}\text { The range of dimensional and shape accuracy on the rim } \\
\text { of a polymer gear wheel, } \mathrm{mm}\end{array}$ \\
\hline before the shaving process & from +0.292 to +0.011 \\
\hline after a single pass of shaving cutter & from +0.243 to +0.009 \\
\hline after a two passes of shaving cutter & from +0.132 to +0.006 \\
\hline after a three passes of shaving cutter & from +0.084 to -0.006 \\
\hline after a four passes of shaving cutter & from +0.021 to -0.003 \\
\hline $\begin{array}{c}\text { PPA35GF } \\
\text { Polymer gear made of composite PPA }+35 \text { wt } \% \text { GF (glass fiber) }\end{array}$ & $\begin{array}{l}\text { The range of dimensional and shape accuracy on the rim } \\
\text { of a polymer gear wheel, } \mathrm{mm}\end{array}$ \\
\hline before the shaving process & from +0.311 to +0.017 \\
\hline after a single pass of shaving cutter & from +0.249 to +0.012 \\
\hline after a two passes of shaving cutter & from +0.172 to +0.008 \\
\hline after a three passes of shaving cutter & from +0.091 to -0.007 \\
\hline after a four passes of shaving cutter & from +0.033 to -0.006 \\
\hline
\end{tabular}




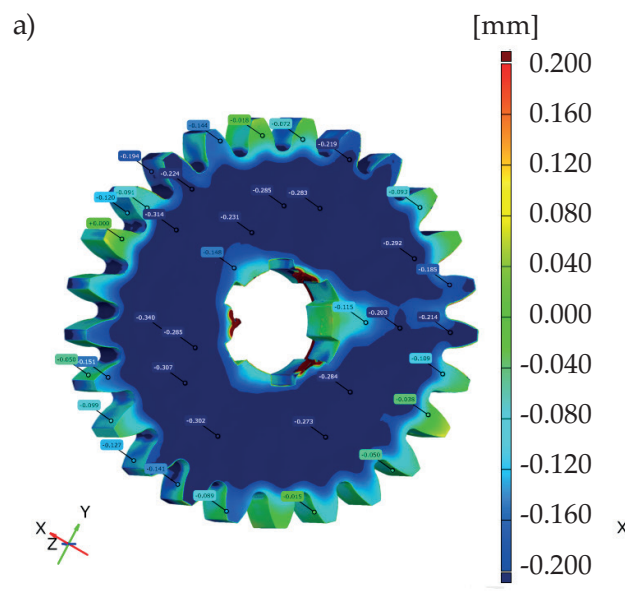

d)

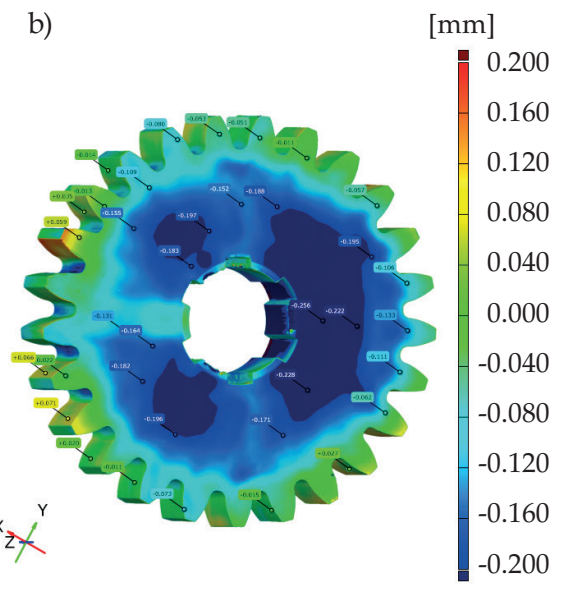

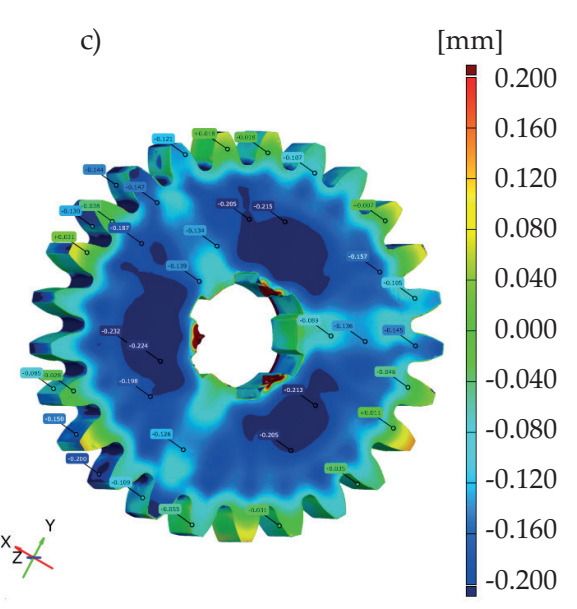

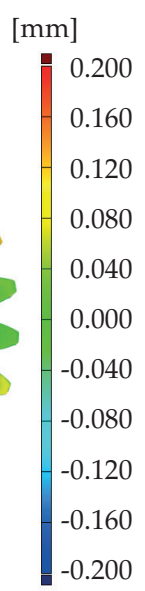

Fig. 3. Detailed specification of the dimensions deviations of the gear made of PA6635GF composite after the following process: a) injection molding, b) first shaving cycle, c) second shaving cycle, d) third shaving cycle, e) fourth shaving cycle

posite with $50 \%$ addition of glass fiber). Before the shaving process, the differences in dimensions on the rim of these wheels ranged - from +0.292 to $+0.011 \mathrm{~mm}$, and after the four-time shaving process from +0.021 to -0.003 $\mathrm{mm}$. Such a clear improvement in the shape and dimensional accuracy of the tested gears will definitely improve the operation of the gear transmission with the use of polymer composite wheels.

\section{CONCLUSIONS}

Based on the conducted research, it can be concluded that:

- The effects of processing polymer gears shrinkage and warping were reduced by the use of the shaving method,

- The best results were obtained for gears after four shaving cycles. The use of non-contact optical measuring systems made it possible to fully assess the impact of shaving on the geometric accuracy of the tested gears,
- Due to the accuracy of polymer gears after the shaving process, gears made of PA50FG composite material can be successfully used in some drive systems as replacements for machine elements made of metals.

\section{REFERENCES}

[1] Markowska O., Markowski T., Sobczyk M.: Polimery 2020, 65, 311. https://dx.doi.org/10.14314/polimery.2020.4.8

[2] Oleksy M.: „Materiały polimerowe stosowane na elementy maszyn", Oficyna Wydawnicza Politechniki Rzeszowskiej, Rzeszów 2019, ISBN 978-83-7934-284-6.

[3] Markowski T.: „Wiórkowanie: podstawy procesu”, Oficyna Wydawnicza Politechniki Rzeszowskiej, Rzeszów 1996.

[4] Dziubek T., Oleksy M.: Polimery 2017, 62, 44. http://dx.doi.org/10.14314/polimery.2017.044

[5] Dziubek T.: Polimery 2018, 63, 49. http://dx.doi.org/10.14314/polimery.2018.049

Received 30 III 2021. 